\title{
Is climate change causing increased rockfall frequency in Austria?
}

\author{
O. Sass ${ }^{1}$ and M. Oberlechner ${ }^{2}$ \\ ${ }^{1}$ Institute for Geography, Innrain 52, 6020 Innsbruck, Austria \\ ${ }^{2}$ Institute for Geography and Spatial Research, Heinrichstr. 36, 8010 Graz, Austria \\ Correspondence to: O. Sass (oliver.sass@uibk.ac.at)
}

Received: 2 February 2012 - Revised: 29 May 2012 - Accepted: 7 June 2012 - Published: 1 November 2012

\begin{abstract}
Potentially, increasing rockfall hazards triggered by climate change are a major concern expressed both in scientific and non-scientific media. An existing rockfall inventory for Austria including 252 events from ca. 1900 to 2010, mainly from non-permafrost areas, was analysed. The correlation of events with temperatures is very weak and no increase of rockfall frequency during warmer periods was observed. The peak of rockfall activity is in spring, whereas in recent decades a secondary summer maximum appeared in the records. A possible reason for this shift is reduced rockfall activity in spring due to warmer winters. We conclude that a premature warning of increasing rockfall hazard, especially below the permafrost limit, is not supported by the existing data.
\end{abstract}

\section{Introduction}

Rockfalls are a considerable threat to settlements and infrastructure in the Alps. The number of media reports on hazardous rockfalls and other geomorphic events has increased in recent years and the amplifying role of climate change is frequently suggested if not stated as de facto. This is exemplified by newspaper headlines such as Will climate change crush our Alps? ("Zerbricht der Klimawandel unsere Alpen?", Bild.de, 2011). In the context of a tragic rockfall event in Bavaria that cost two lives (Bild.de, 2010), the President of the Bavarian State Office for the Environment (LFU) stated in an interview that higher rainfall and a more rapid succession of cold and warm phases would accelerate erosion and rockfall, and that we are currently experiencing a "destabilisation of our mountain regions". In scientific publications, the question of currently-intensifying natural hazards in mountain regions is also a matter of debate (Berz, 2009). Rockfall is presumed to be a direct and perhaps unexpectedly rapid impact of climate change due to permafrost degradation (Gruber et al., 2004). This viewpoint was supported in the exceptionally warm summer of 2003 when heightened rockfall activity was reported throughout the Alps, especially at high elevations and on north-facing slopes (Gruber et al., 2004; Nötzli et al., 2004). Numerous case studies reporting spectacular rock and ice avalanches, e.g. in Kolka-Karmadon, Caucasus (Haeberli et al., 2004) or Mt. Steele, Canada (Lipovsky et al., 2008) further support this view. However, even if some of the reported events can be unequivocally assigned to the current warming trend (e.g. Deline et al., 2008), there are two major flaws found in many of the statements. First, information on historical rockfall activity is widely missing, as there are very few investigations or inventories of the temporal distribution of rockfalls in the past (although, see the study by Ravanel and Deline, 2008, in the Mont Blanc area as a rare exception). Thus, it is not always clear if similar events have also taken place in cooler periods. Second, research activities are strongly biased towards glaciated or permafrost areas, whereas most of the rockfall events threatening infrastructure and structures derive from slopes which are far below the permafrost line. Typical examples are the rockfall at Huben/Längenfels (Tyrol) on 11 March 1999 (Fig. 1) and the rockfall at Koblach (Vorarlberg) on 19 June 2010 (orf.at, 2010).

While numerous publications deal with spatial rockfall distribution and slope susceptibility (e.g. Santi et al., 2009), investigations on the longer-term temporal behaviour are rare. Moreiras (2006) emphasized the strong bias of historical records and pointed out the importance of wet phases for rockfall generation. In a dendroecological approach, Perret et al. (2006) found rockfall rates to be positively correlated with mean temperatures; however, they found no correlation with annual or seasonal precipitation totals. In a similar approach, Schneuwly and Stoffel (2008) established strong interannual 


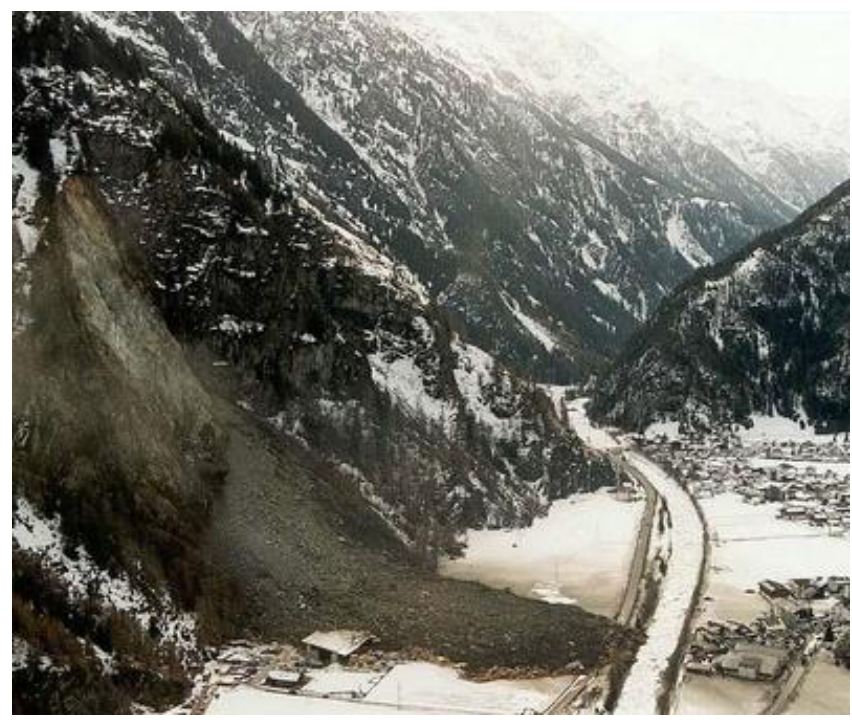

Fig. 1. Rockfall of Huben (Austria) that destroyed a sawmill on 11 March 1999. The rockfall originated from the over-steepened valley flank of the Ötztal far below the permafrost reaches. Photograph by die.wildbach, taken from www.nachhaltigkeit.at.

variations and single event years with increased activity. As contrasted with this rather fragmentary evidence, the negative influence of permafrost degradation on rock stability seems to be beyond debate as there is a relatively straightforward relation of cause and effect. Warming causes permafrost to degrade and thus the cementing material is lost (e.g. Fischer et al., 2006). Even the warming of ice without actual melt has been reported to promote failure because the shear resistivity of warmer ice decreases, entering a zone of minimal stability between -1.5 and $0{ }^{\circ} \mathrm{C}$ (Davies et al., 2001; Krautblatter and Funk, 2010). Deline et al. (2008) attributed $55 \%$ of the rockfalls observed in the Mont Blanc massif in 2007 and 2008 to permafrost degradation, and Allen et al. (2009) found that 13 out of 19 rockfalls investigated in New Zealand derived from marginal permafrost areas. However, despite the strong research focus on the cryosphere in the Alps, it needs to be emphasized that glaciers actually cover only less than $1 \%$ of the Austrian Alps and frozen ground is present in no more than 3-4\% of the area (Lieb, 2000). However, especially in non-scientific media, neither the processes (rockfalls and landslides of different magnitudes, debris-flows) nor the source areas (permafrost or nonpermafrost areas) are clearly described. Based on rockfall inventory data from Switzerland, Gruner (2004) stated that a generally increasing frequency of rockfalls at present is not recognisable and not to be expected in the nearer future. The aims of this article are to add inventory data from Austria to the discussion and to analyse whether or not an effect from climate change can be inferred from the dataset.

\section{Rockfalls and their definition}

There is a plethora of different terminologies for geomorphic mass movements. Rockfalls are commonly referred to as free-falling movements of detached bedrock particles from a rock face (e.g. Whalley, 1974). According to the most commonly used German definition (e.g. Ahnert, 2003), three ranges of rockfall volumes are distinguished: Steinschlag (small events of up to a few $\mathrm{m}^{3}$ ), Felssturz (intermediate events of up to $10^{6} \mathrm{~m}^{3}$ ) and the larger Bergsturz events. In English terminology, Whalley (1974) presented a strictly quantitative subdivision in debris fall $\left(<10 \mathrm{~m}^{3}\right)$, boulder fall $\left(10-10^{2} \mathrm{~m}^{3}\right)$, block fall $\left(10^{2}-10^{4} \mathrm{~m}^{3}\right)$, cliff fall $\left(10^{4}-10^{6} \mathrm{~m}^{3}\right)$ and bergsturz $\left(>10^{6} \mathrm{~m}^{3}\right)$. However, numerous additional terms such as landslide, rockslide and rock avalanche are also in use.

We restrict our evaluation to the mid-magnitude range from boulder fall to cliff fall ("Felssturz" in German) for the following reasons: (1) small-scale debris falls are usually not reported in the media and are a minor threat to infrastructure (even if they are of interest for road maintenance and for mountaineers). They are usually governed by shortterm weather conditions like freeze-thaw events or precipitation (Sass, 2005; Krautblatter et al., 2012). (2) Major rockfalls (bergsturz) are too rare to be adequately represented in a dataset covering ca. 100 yr. Prager et al. (2008) compiled dating results from numerous bergsturz events in Tyrol and found a relatively even temporal distribution in the Holocene which is indicative of long-term geological triggers (stress release) rather than climatic control. Thus, rockfalls of intermediate size are thought to be most of all influenced by climate fluctuations on the time scale of decades. Cold winter temperatures cause bedrock contraction and promote the formation or propagation of clefts (Gruner, 2008). Possible trigger mechanisms involve hydrostatic pressure of pore water, which may be particularly evident in spring when meltwater adds to the first rainfall events (Krähenbühl, 2004). Furthermore, permafrost degradation is a significant rockfall trigger at high elevations, although this is not discussed in this article (see Introduction and references therein).

\section{The dataset}

The study is based on the database provided by the Austrian Geologic Survey (Kautz et al., 2006; Geologische Bundesanstalt, 2011) which lists mass movements of public interest and media response, and which also includes large historical events from chronicles. The data are freely accessible on the internet as a GeoMap application ("Massenbewegungen online"); the Geologic Survey provides the data in tabular form. The dataset is incomplete because in the past no systematic data collection was performed. It is assumed that reasonable completeness was not achieved until the last decade, in which 
the availability of newspapers and reports on the internet has strongly increased.

A considerable bias in the long-term distribution has to be considered. Due to the experience of the persons in charge at the Geologic Survey, more and more information pertaining mass movements (local newspapers, administrative reports, diploma theses, etc) have been put online in recent decades. Furthermore, permanent settlement areas and infrastructure in the Alps are constantly increasing, which implies an increasing number of damage reports. Finally, natural hazards and protection measures have become very important on the political agenda, entailing more and more media reports. Sound quantification of this growing number of reports is not possible; however, the general increase in information is unquestionable.

The dataset was filtered for rockfalls according to the definitions provided above. Due to the imprecise terminology, this involved a broad range of terms (specified below). Events were considered for evaluation when the main criteria (rather rapid, free falling movement of stones or boulders) seemed to be fulfilled. For example, so-called "bergsturz" events were also considered if the estimated volume did not exceed $10^{6} \mathrm{~m}^{3}$. Due to the plethora of terms and their indistinct use, misinterpretation of a very few events may have occurred.

Terms, or combination of terms, considered as "rockfalls":

\section{German:}

Felssturz, Blocksturz, Bergsturz, Steinfall, (massiver) Steinschlag, Felssturz mit anschließender Mure, Felsgleitung, Felssackung, Steinlawine, Felssturz mit Rutschung

\section{rough translation:}

Rockfall ( $\approx$ boulder fall, block fall, cliff fall), bergsturz, (massive) debris fall, rockfall with subsequent debris flow, rock slide, rock sagging, rock avalanche, rockfall with landslide

For many events, no more than a very approximate location has been documented. All datasets used in this contribution were individually checked by the authors using digital maps. It was possible to locate the most probable source area for almost every rockfall with an accuracy of a few hundred altitude meters. Events were considered only if a date (at least: year and month) was available. With the exception of a small number of historical events before 1900, all data derives from the 20th and 21st century. Accordingly, our evaluated dataset starts in 1901 and ends in 2010. As data density is low for the first decades of this period and much higher for the last decade, the 21 st century data was blanked out or evaluated separately in some figures.

\section{Meteorological data}

It was not possible, nor did we intend, to provide meteorological data for each of the rockfalls in the database, as the focus was on the long-term behaviour rather than on individual triggers. Thus, the meteorological station Rauris at an elevation of $950 \mathrm{~m}$ was chosen for reference, because it is at a central location within the Austrian Alps and temperature data are available for the complete evaluation period. The data were downloaded from the web server of the Austrian Central Institute for Meteorology and Geodynamics (ZAMG, 2008) and had to be corrected and homogenised before use. For the analysis of the last decade, averaged climate data from 30 evenly distributed stations in the Austrian Alps (zamg.ac.at, 2011) were used. We calculated mean temperature values for the meteorological seasons (December-February, March-May, JuneAugust, September-November). For the mean of the winter season, the December data of the respective preceding year was used.

\section{Results}

Between 1901 and 2010, a total of 252 rockfalls (according to the definition outlined above) were registered and documented in all of Austria, leaving out the federal states of Burgenland and Vienna which have no share of the Alps. This equates to 3.2 events per $1000 \mathrm{~km}^{2}$ or 0.029 events per $1000 \mathrm{~km}^{2}$ per year. As one would expect, the majority of rockfalls occurred in the western federal states of Austria which feature a high proportion of mountainous terrain. A total of $24 \%$ of the rockfalls occurred in Tyrol and $17 \%$ in each Salzburg and Upper Austria. The smallest federal state of Vorarlberg is number one in terms of rockfalls per unit area $\left(13.5\right.$ per $\left.1000 \mathrm{~km}^{2}\right)$.

The vast majority of the registered rockfalls $(91 \%)$ took place at elevations of below $2100 \mathrm{~m}$ which means that they are, in all probability, not influenced by permafrost. More than $50 \%$ of the events occurred close to the valley floors at the lowest elevation range of 300-900 m (Fig. 2a). The seasonal distribution between the low-elevation and the highelevation events is markedly different (Fig. 2b) and is discussed later.

The temporal distribution (Fig. 3a) shows a pronounced maximum in the last decade. This is due to the inherent bias of the dataset caused by the better documentation in the 1990s and particularly in the 21st century. Despite this bias, smaller maxima in the 1930s and in the 1970s can be observed. The annual data from 1995 onwards clearly show a linear increase (Fig. 3b), which we also assign to the steadily enhanced documentation as explained in the methodology section. When this linear trend is removed, only a few abnormalities are apparent. The number of rockfalls in 2007 is clearly below average, whereas the number is slightly above 

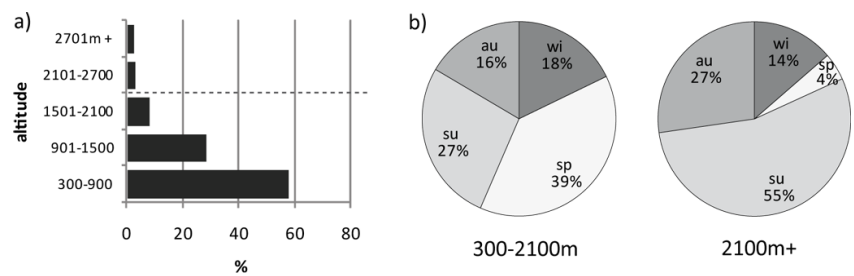

Fig. 2. (a) Rockfall distribution with elevation; (b) seasonal distribution in the two rough elevation ranges "probably below permafrost line" (300-2100 m) and "possibly permafrost-influenced" $(>2100 \mathrm{~m}) . \mathrm{wi}=$ winter, $\mathrm{sp}=$ spring, $\mathrm{su}=$ summer, $\mathrm{au}=$ autumn .

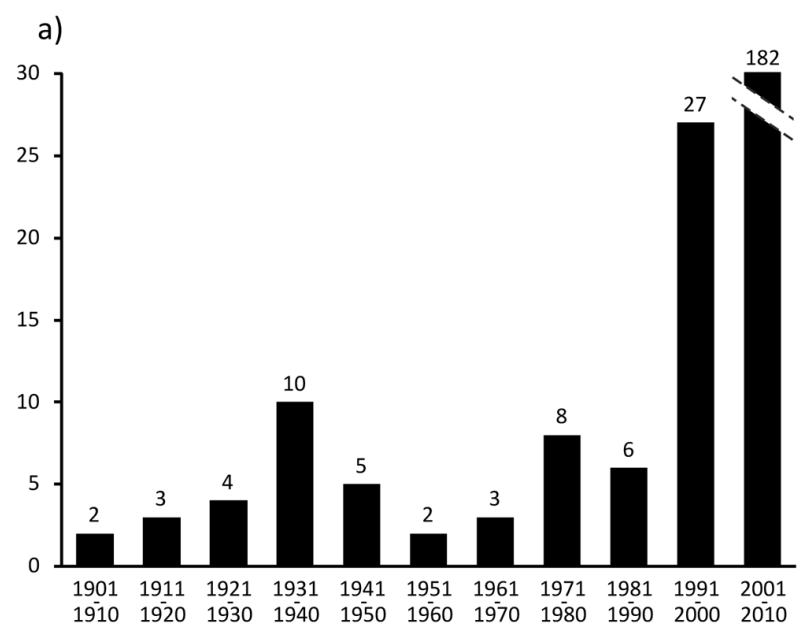

b)

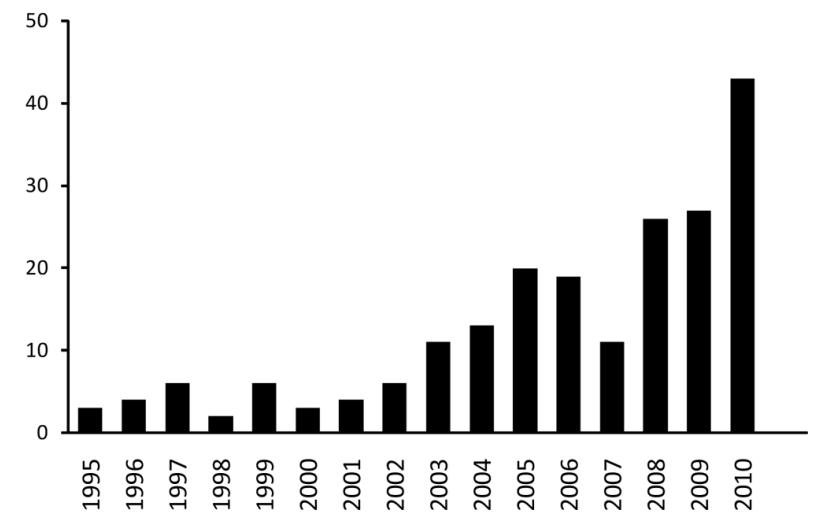

Fig. 3. (a) Rockfall count on the decadal scale from 1900-2010; (b) annual rockfall count from 1995-2010.

average in 2008. Remarkably, the year 2003, with its exceptionally warm summer, is normal in terms of rockfall occurrence.

\subsection{Correlation with seasonal and annual temperature}

To avoid the bias towards the last 1 to 2 decades, the first analysis was carried out only with the data from 1900 to 1995. The annual number of rockfalls correlates neither with
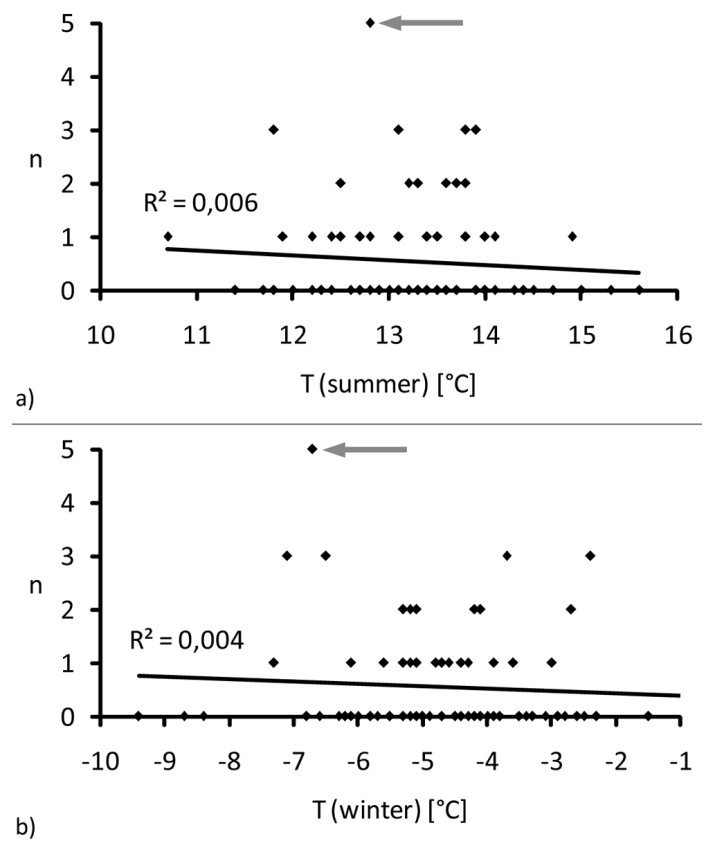

b)

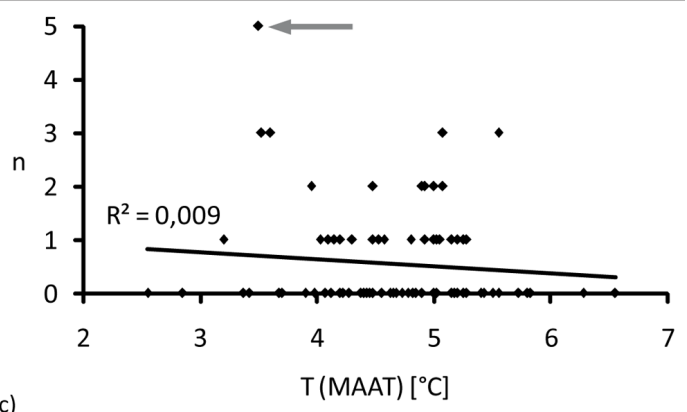

Fig. 4. (a-c) Correlation of the annual rockfall count (years 19001995) with mean summer temperatures (June-August), mean winter temperatures (December-February) and mean annual temperatures. Arrows: year 1931 (see text).

mean annual temperatures, nor with the mean temperatures of the respective summer or winter season (Fig. $4 a-c)$. The insignificant correlation $\left(R^{2} \leq 1 \%\right)$ points towards a slight decrease of rockfall count with higher temperatures. In 1931, the maximum of five rockfalls occurred (arrows in Fig. 4); this year is among the ten coldest in terms of mean annual temperature and of winter temperature.

\subsection{Seasonal distribution}

The monthly distribution of rockfalls for three time periods was analysed: 1901-1950 as a period of moderate warming, 1951-1980 as a relatively cooler period, and the current period of rapid warming from 1981 to 2010 (Fig. 5). To aid comparability, these three phases are the same as used by Gruner (2004) in Switzerland. On average, March is the month with the highest rockfall activity ( $15 \%$ of all events). Rockfalls in the first period (1901-1950) had a maximum 


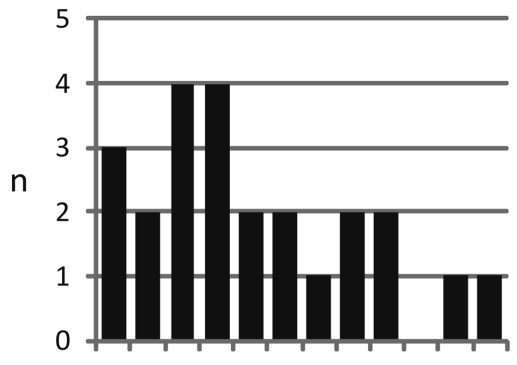

J FMAM J J A SOND months (1901 to 1950 )
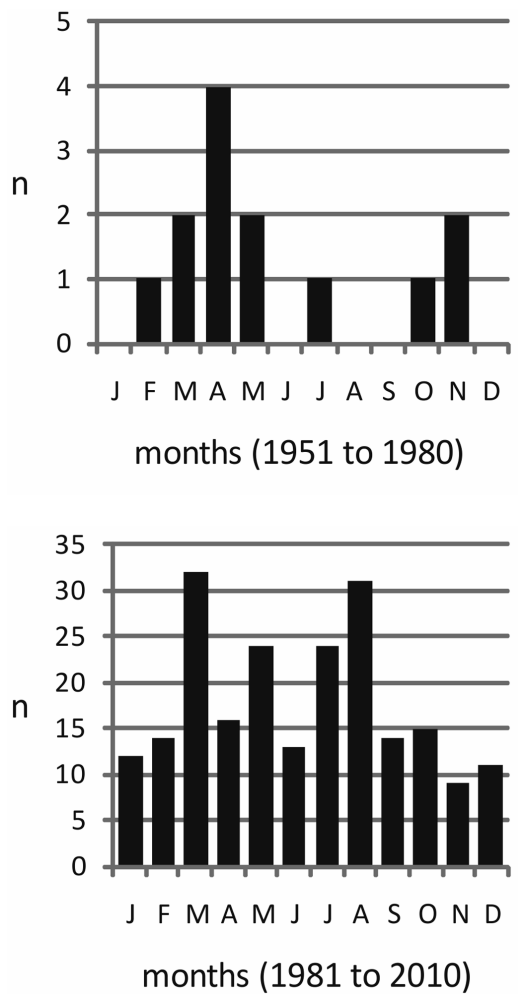

Fig. 5. (a-c) Monthly distribution of rockfalls in the periods 19011950, 1951-1980 and 1981-2010.

in spring and lower counts in summer. In the cooler second phase (1951-1980), this spring peak is even more pronounced. A possible reason would be bedrock contraction and cracking in cold winters. In the recent warming phase, the spring maximum is still apparent; however, a secondary maximum appears in the summer months (Fig. 5c). This increase might be explained by climate warming and an increasing frequency of heavy precipitation events; however, before conclusions can be drawn this needs to be examined in greater detail.
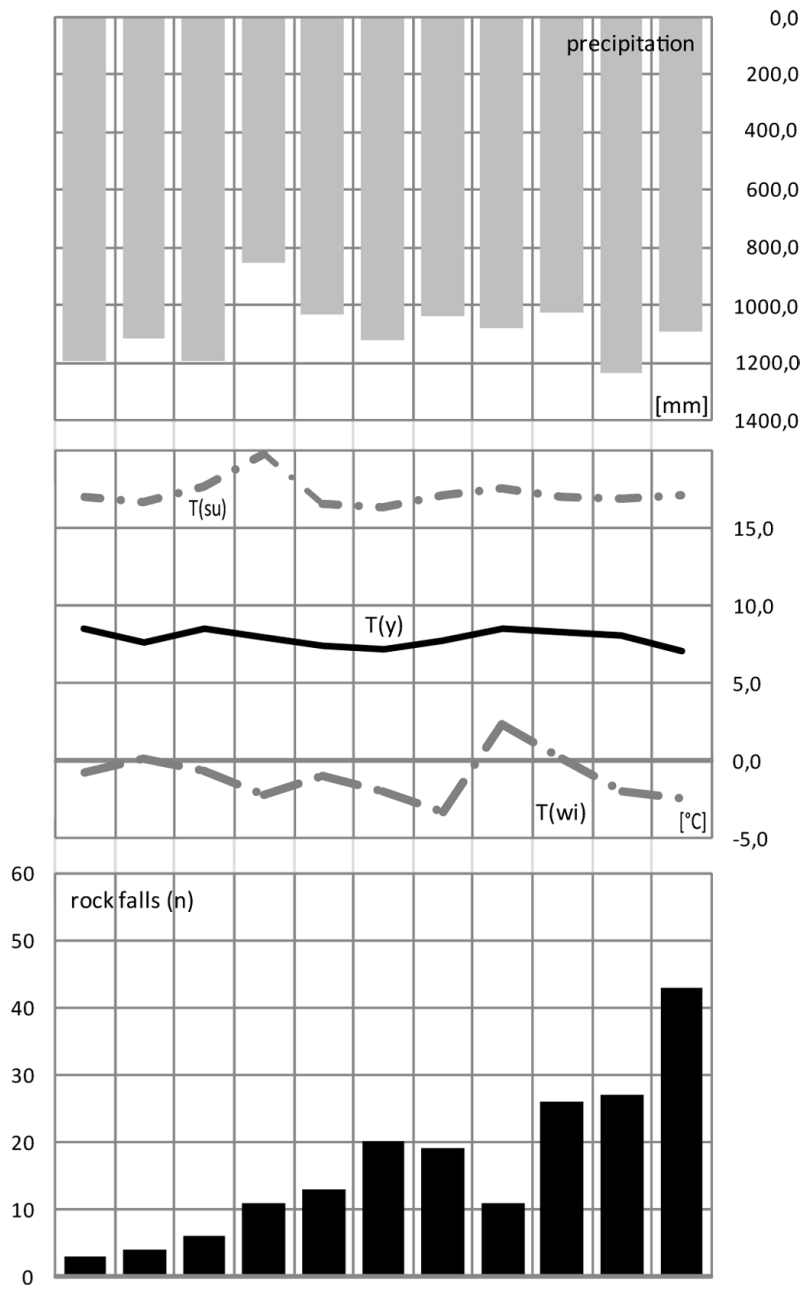

20002001200220032004200520062007200820092010 year

Fig. 6. Annual rockfall distribution between 2000 and 2010 together with meteorological parameters. $T(y)$ : mean annual temperature; $T(\mathrm{su})$ : mean summer temperature (June-August); $T$ (wi): mean winter temperature (December-February). Marked rockfall decrease in 2007 is probably due to an internal inconsistency of the database.

\subsection{The decade 2000-2010}

Because of the significantly improved documentation in the last decade, this period is treated separately using an annual time span. In Fig. 6, the annual rockfall count is compared to mean winter, summer, and annual temperatures, and to annual rainfall.

The bias towards better documentation in recent years has to be considered. If this steady increase is removed, the years 2005, 2008 and 2010 appear to be relatively high, whereas in 2007, the rockfall count is relatively low. The correlation with meteorological data is very weak, if present at all. Cold winter temperatures could be responsible for elevated rockfall counts in 2005 and 2010. However, similar 
winter temperatures in 2009 did not cause a similar response, whereas the markedly warm winter of 2006 is also accompanied by comparatively high rockfall numbers. Summer temperatures are relatively even throughout the decade with the exception of the year 2003. This very warm summer only caused very minor (if any) rockfall increase; a statistical analysis shows that the proportion of summer rockfalls is not higher in 2003 than it is in the other years. The highest annual mean temperature was registered in $2007\left(8.6^{\circ} \mathrm{C}\right)$ and was accompanied by markedly less rockfall than in the years before and after; interestingly, this warm year was due mainly to an unusually warm winter. However, as the person in charge at the Geologic Survey changed in this year (A. Kociu, GBA, personal communication, 2012), the decrease in rockfall numbers could be due an internal inconsistency of the database and should not be over interpreted. There is no apparent correlation with precipitation: in years standing out for above-average precipitation (e.g. 2002: $1194 \mathrm{~mm}$; 2009: $1232 \mathrm{~mm}$ ), no particularly high rockfall count was observed. The exceptionally dry year of $2003(850 \mathrm{~mm})$ is also well within the general trend.

\section{Discussion}

The dataset used for the analysis is clearly inconsistent and biased; any conclusions regarding the impact of climate change have to be treated with caution. The incomplete database makes statistically rigorous analysis challenging; the same problem was noted by e.g. Moreiras (2006), and by Huggel et al. (2010) and Dikau et al. (1996) for landslide reports. A significant correlation to temperature is not to be expected because the overview approach does not take into account the specific microclimatic situation for each of the single events. However, the focus is on overarching trends, and these cannot be found in the data. As the comparison between the older and the younger data (last century vs. last decade) is not possible, there is currently no indication of increasing rockfall counts caused by climate warming outside of permafrost areas. Gruner (2008) came to the same conclusion in Switzerland. Regarding the decadal or annual scale, there is also no clear relation towards increasing rockfall in warmer periods. At best, there is a tendency towards higher rockfall counts in cold years, especially after cold winters. Based on rock deformation measurements, Gruner (2004) attributes this phenomenon to joint widening during cold temperatures. Krähenbühl (2004) also assumes that annual temperature fluctuations, especially deep winter temperatures, are the most important factor of bedrock destabilising. Sass (2005) also found that debris fall rates are correlated with cold winter temperatures rather than with other meteorological triggers like freeze-thaw activity.

The intra-annual distribution is not affected by the shortcomings of the database as there is no sensible reason to assume that rockfalls in one season should be less documented than in others. We found a rockfall maximum in spring which coincides with the dendroecological results of Perret et al. (2006) and Schneuwly and Stoffel (2008). A similar pattern was also found by Sandersen et al. (1995) in Norway. They attribute the heightened geomorphic activity to increased water supply caused by snowmelt and rainfall, as well as intensified freeze-thaw activity. Gruner $(2004,2008)$ found similar results in Switzerland and explains the spring peak through bedrock contraction in winter followed by hydrostatic pressure.

For warmer periods like the last decades, a percentage shift of the rockfall distribution into the summer months (and thus, a more even monthly distribution) was noted. As pointed out, this shift is not affected by the aforementioned weaknesses of the database. Gruner (2004) attributes this phenomenon to increasing frequencies of extreme precipitation events due to climate warming (IPCC, 2007; Wild et al., 2008). However, premature conclusions should be avoided as projections of precipitation change for Austria and the entire Alpine region are still very uncertain (e.g. Heinrich and Gobiet, 2011). According to Fürst et al. (2008), overall precipitation trends for Austria are very weak and statistically insignificant with inhomogeneous tendencies on both a seasonal and spatial scale. Rudel (2008) points out that for the last ca. $50 \mathrm{yr}$ in Austria, no increase in extreme precipitation events was observed. Thus, we attribute the shift of the temporal distribution rather to a decrease of event counts in spring than to an increase in summer. If we experience warmer winters in the decades to come (Matulla et al., 2004), rockfall activity in winter and spring might further decrease. Enhanced frequencies of rainstorm events (for which there is currently no indication) could potentially amplify the secondary maximum in summer which has been observed in the last decades. Intensifying rockfall at higher elevations due to permafrost degradation will add to this increase. Taken together, these tendencies would lead to a more even distribution of rockfall events between the seasons. Once again, it needs to be emphasized that site-specific changes in micro-climatic conditions (e.g. temporal and spatial shifts of local snow loads) cannot be inferred from the database.

Reports and documentation on rockfall hazards in the Alps have multiplied in recent decades. Laying the blame on climate warming as frequently observed in the public media (and sometimes willingly taken on by the scientific community) should be avoided as for most of Austria, no correlation between warming and rockfall frequency can be found. With warmer summers in the coming decades, we will likely experience heightened rockfall frequency in retreating permafrost areas. However, in the much larger permafrost-free regions, milder winters will possibly reduce the number of rockfalls. Whether increasing precipitation and thus, higher pore pressures will counteract this effect is unclear. However, at this moment in time there is no reason to assume a general increase of annual rockfall counts below the permafrost limit in Austria. This finding contradicts the many warnings found in 
public media and also to the simplifying general statements of the IPCC assessment report (2007) in which an overall increase of geomorphic hazards in alpine regions is predicted.

Acknowledgements. We wish to express our sincere thanks to the Austrian Geologic Survey for compiling and providing the database and particularly to Arben Kociu for additional information. Furthermore, we thank two anonymous reviewers for their helpful comments, and Lisa Mol and Mark Williams for their corrections on the English.

Edited by: D. Keefer

Reviewed by: P. T. Bobrowsky and another anonymous referee

\section{References}

Ahnert, F.: Einführung in die Geomorphologie, 3. Aktualisierte und ergänzte Auflage, Eugen Ulmer Verlag, Stuttgart, Germany, 477 pp., 2003.

Allen, S. K., Gruber, S., and Owens, I. F.: Exploring steep permafrost bedrock and its relationship with recent slope failures in the Southern Alps of New Zealand, Permafrost Periglac., 20, 345-356, 2009.

Berz, G.: Natural Disasters and Climate Change in the Alps, Alpine Space Man. Environ., 7, 53-60, 2009.

Bild.de: Felssturz Stein an der Traun mit zwei Toten: Ist der Klimawandel schuld? - News - Bild.de, available at: http://www.bild.de/news/2010/alpen/ schuld-an-katastrophe-in-stein-11263414.bild.html (last access: 18 May 2011), 2010.

Davies, M. C. R., Hamza, O., and Harris, C.: The effect of rise in mean annual temperature on the stability of rock slopes containing ice-filled discontinuities, Permafrost Periglac., 12, 137-144, 2001.

Deline, P., Kirkbride, M. P., Ravanel, L., and Ravello, M.: The Tréla-Tete rockfall onto the Lex Blanche glacier, Mont Blanc massif, Italy, in September 2008, Geogr. Fis. Dinam. Quat., 31, 251-254, 2008.

Dikau, R., Cavallin, A., and Jäger, S.: Databases and GIS for landslide research in Europe, Geomorphology, 15, 227-239, 1996.

Fischer, L., Kääb, A., Huggel, C., and Noetzli, J.: Geology, glacier retreat and permafrost degradation as controlling factors of slope instabilities in a high-mountain rock wall: the Monte Rosa east face, Nat. Hazards Earth Syst. Sci., 6, 761-772, doi:10.5194/nhess-6-761-2006, 2006.

Fürst, J., Kling, H., Nachtnebel, H. P., and Hörhan, T.: Trends in hydrologischen Variablen und in der Wasserbilanz Österreichs, in: Auswirkungen des Klimawandels auf die österreichische Wasserwirtschaft, Bundesministerium für Landund Forstwirtschaft, Umwelt und Wasserwirtschaft, Vienna, Austria, 105-115, 2008.

Geologische Bundesanstalt: Massenbewegungen online DeutschEnglisch, available at: http://geomap.geolba.ac.at/MASS/index. cfm, last access: 15 May 2011.

Gruber, S., Hoelzle, M., and Haeberli, W.: Permafrost thaw and destabilization of Alpine rock walls in the hot summer 2003, Geophys. Res. Lett., 31, L13504, doi:10.1029/2004GL020051, 2004.
Gruner, U.: Klima und Sturzereignisse in Vergangenheit und Zukunft, Bulletin für angewandte Geologie, 12, 23-37, 2004.

Gruner, U.: Klimatische und meteorologische Einflüsse auf Sturzprozesse, Interprävent, 147-158, 2008.

Haeberli, W., Huggel, C., Kääb, A., Oswald, S., Polkvoj, A., Zotikov, I., and Osokin, N.: The Kolka-Karmadon rock/ice slide of 20 September 2002 - An extraordinary event of historical dimensions in North Ossetia (Russian Caucasus), J. Glaciol., 50, 533-546, 2004.

Heinrich, G. and Gobiet, A.: Expected climate change and its uncertainty in the Alpine Region, WEGC Report to ACRP No. 2/2011, Wegener Center for Climate and Global Change, University of Graz, Austria, 2011.

Huggel, C., Salzmann, N., Allen, S., Caplan-Auerbach, J., Fischer, L., Haeberli, W., Larsen, C., Schneider, D., and Wessels, R.: Recent and future warm extreme events and high-mountain slope stability, Philos. T. Roy. Soc. A, 368, 2435-2459, 2010.

IPCC assessment report: Klimaänderung 2007 - synthesis report, available at: http://www.de-ipcc.de/_media/ IPCC-SynRepComplete_final.pdf (last access 21 May 2011), 2007.

Kautz, H., Tilch, N., Reischer, J., and Heger, H.: OnlineInformationssystem Massenbewegungen in Österreich an der Geologischen Bundesanstalt, edited by: Tessadri-Wackerle, M., PANGEO Austria 2006, Innsbruck University Press (IUP), 136137, 2006.

Krähenbühl, R.: Temperatur und Kluftwasser als Ursachen von Felssturz, Bulletin für angewandte Geologie, 7, 19-35, 2004.

Krautblatter, M. and Funk, D.: A Rock-/Ice Mechanical Model for the Destabilisation of Permafrost Rocks and First Laboratory Evidence for the "Reduced Friction Hypothesis", in: Proc. 3rd European Conference on Permafrost, Svalbard, Spitsbergen, Norway, p. 205, 2010.

Krautblatter, M., Moser, M., Schrott, L., Wolf, J., and Morche, D.: Significance of rockfall magnitude and carbonate dissolution for rock slope erosion and geomorphic work on Alpine limestone cliffs (Reintal, German Alps), Geomorphology, in press, 2012.

Lieb, G. K.: Hochgebirgspermafrost in den österreichischen Alpen, Österreich in Geschichte und Literatur mit Geographie, 44, 4959, 2000.

Lipovsky, P. S., Evans, S. G., Clague, J. J., Hopkinson, C., Couture, R., Bobrowsky, P., Ekström, G., Demuth, M. N., Delaney, K. B., and Roberts, N. J.: The July 2007 rock and ice avalanches at Mount Steele, St. Elias Mountains, Yukon, Canada, Landslides, 5, 445-455, 2008.

Matulla, C., Formayer, H., Haas, P., and Kromp-Kolb, H.: Possible climate trends in Austria in the first half of the 21st century, OeWAW, 56, 1-9, 2004.

Moreiras, S. M.: Frequency of debris flows and rockfall along the Mendoza river valley (Central Andes), Argentina: Associated risk and future scenario, Quaternary Int., 158, 110-121, 2006.

Nötzli, J., Gruber, S., and Hölzle, M.: Permafrost und Felsstürze im Hitzesommer 2003, GEOforum actuel, 20, 11-14, 2004.

orf.at: Felssturz: Weitere Steinschläge möglich - oesterreich.orf.at, available at: http://vorarlberg.orf.at/stories/450801/ (last access: 27 January 2012), 2010.

Perret, S., Stoffel, M., and Kienholz, H.: Spatial and temporal rockfall activity in a forest stand in the Swiss Prealps - a dendrogeomorphological case study, Geomorphology, 74, 219-231, 2006. 
Prager, C., Zangerl, C., Patzelt, G., and Brandner, R.: Age distribution of fossil landslides in the Tyrol (Austria) and its surrounding areas, Nat. Hazards Earth Syst. Sci., 8, 377-407, doi:10.5194/nhess-8-377-2008, 2008.

Rudel, E.: Einige Gedanken zur Frage der Zunahme der meteorologischen Extremwerte, in: Auswirkungen des Klimawandels auf die österreichische Wasserwirtschaft, Bundesministerium für Land- und Forstwirtschaft, Umwelt und Wasserwirtschaft, Vienna, Austria, 83-91, 2008.

Ravanel, L. and Deline, P.: La face ouest des Drus (massif du Mont-Blanc), Évolution de l'instabilité d'une paroi rocheuse dans la haute montagne alpine depuis la fin du petit age glaciaire, Géomorphologie, 4, 261-272, 2008.

Sandersen, F., Bakkehoi, S., Hestnes, E., and Lied, K.: The influence of meteorological factors on the initiation of debris flows, rockfalls, rockslides and rockmass stability, in: Landslides 1996, Balkema, Rotterdam, Netherlands, 97-113, 1995.

Santi, P. M., Russell, C. P, Higgins, J. D., and Spriet, J. I.: Modification and statistical analysis of the Colorado Rockfall Hazard Rating System, Eng. Geol., 104, 55-65, 2009.
Sass, O.: Temporal variability of rockfall in the Bavarian Alps, Germany, Arc Antarc. Alp. Res., 37, 564-573, 2005.

Schneuwly, D. M. and Stoffel, M.: Spatial analysis of rockfall activity, bounce heights and geomorphic changes over the last 50 years - a case study using dendrogeomorphology, Geomorphology, 102, 522-531, 2008.

Whalley, W. B.: The mechanics of high magnitude-low frequency rock failure and its importance in mountainous areas, Geogr. Papers, Reading University, UK, 1974.

Wild, M., Gieser, J., and Schär, C.: Combined surface solar brightening and increasing greenhouse effect support recent intensification of the global land-based hydrological cycle, Geophys. Res. Lett., 35, L17706, doi:10.1029/2008GL034842, 2008.

ZAMG (Zentralanstalt für Meteorologie und Geodynamik): Homepage of the project "A Tale of Two Valleys", available at: http: //www.zamg.ac.at/a-tale-of-two-valleys/ (last access: 25 May 2011), 2008.

ZAMG (Zentralanstalt für Meteorologie und Geodynamik): ZAMG - Klimawerte, available at: http://www.zamg.ac.at/klima/klima monat/klimawerte/ (last access 25 May 2011), 2011. 